UDC 342.9-053.74

Hurin Dmytro,

Postgraduate at the Kyiv International University,

Kyiv, Ukraine

\title{
THE AVAILABILITY OF WELL-FOUNDED FEAR OF BEING A VICTIM OF PERSECUTION AS A NECESSARY CONDITION FOR RECOGNITION OF ADMINISTRATIVE AND LEGAL REFUGEE STATUS
}

The article investigates the criterion of a well-founded fear of becoming a victim of persecution as a necessary condition for recognition of administrative and legal status of a refugee. The legal framework for granting refugee status in Ukraine has been analysed. Attention is focused on international legal instruments that clarifying the concept of a "refugee" and defining the criteria for granting such status, as adopted by the international community. It has been noted that the criterion of a well-founded fear of persecution as a necessary condition for the recognition of a person as a refugee is established in international law and enshrined in the Statute of the Office of the UN High Commissioner for Refugees (OHCR UN) (1950), the UN Convention relating to the Status of Refugees (1951) and the Protocol on Refugee Status (1967). In addition, the criteria for determining a person as a refugee are set out in the OHCR UN Handbook on Procedures and Criteria for Determining Refugee Status, which was developed and published in 1979 and is a compilation of OHCR UN practical experience, State practice, OHCR UN Executive Committee generalizations, scientific approaches and judicial decisions at the national, regional and international levels. One of the key criteria for recognizing "refugee" status - a well-founded fear of persecution - has been explored, which in our view covers two sub-criteria - well-founded fear and persecution.

Each sub-criterion is considered separately. The "well-founded fear" subcriterion is a reasonable combination of subjective and objective elements that should be factored into determining whether a person has a "well-founded fear of persecution" criterion. "Fear" should not be aimed at anything, but at confirming that a person, 
having returned to the country of their nationality, is afraid to become a victim of persecution. The term "persecution" is not defined in the OHCR UN Charter, the UN Convention relating to the Status of Refugees (1951) or the Charter of the Office of the UN High Commissioner for Refugees (1950).

But paragraph 3, 4 of the OHCR UN position, set out on 14.03.1995, determines that prosecution includes all serious human rights violations. However, there are two views among scholars on the definition of persecution - as a threat to life and freedom, and as a violation of universally recognized human rights.

It has been summed up that the criterion of " well-founded fear of persecution" as a criterion for recognizing a person as a refugee consists in a person's subjective attitude towards the possibility that his or her fundamental rights and freedoms may be violated (primarily the threat to life or freedom that exists) in the circumstances that have developed in the country of nationality if he or she returns to it.

Keywords: refugee, persecution, well-founded fear, legal status, refugee recognition criterion.

\section{REFERENCES}

1. 20 chervnia - Vsesvitnii den bizhentsia. Derzhavna Mihratsiina Sluzhba Ukrainy. "June 20 is World Refugee Day". State Migration Service of Ukraine. URL: https://dmsu.gov.ua/news/dms/vsesvitnij-den-bizhenczya.html (date of application: 15.10.2019) [in Ukrainian].

2. 18 hrudnia - Mizhnarodnyi den mihranta. Derzhavna Mihratsiina Sluzhba Ukrainy. "December 18 is International Migrant Day". State Migration Service of Ukraine. URL: https://dmsu.gov.ua/news/dms/6388.html (date of application: 15.10.2019) [in Ukrainian].

3. Bezhentsy v Ukraine: Migratsionnaia sluzhba obnarodovala statistiku. "Refugees in Ukraine: The Migration Service released statistics". Telegraph: news of Ukraine and the world. URL: https://telegraf.com.ua/ukraina/obshhestvo/3887573bezhentsyi-v-ukraine-migratsionnaya-sluzhba-obnarodovala-statistiku.html (date of application: 15.10.2019) [in Russian].

4. Postanova vid 27.03.2019 po spravi № 1540/3703/18 Piatyi apeliatsiinyi administratyvnyi sud. "Resolution of 27.03.2019 in case No. 1540/3703/18 Fifth 
Administrative Court of Appeal". Zakon online. URL: https://zakononline.com.ua/court-decisions/show/80805066

5. Vyznannia statusu bizhentsia, poboiuvannia peresliduvannia. Postanova Kasatsiinoho sudu N 820130916 vid 23.05.18. "Recognition of refugee status, fear of persecution. Resolution of the Court of Cassation No.820130916 dated 23.05.18". URL:

https://protocol.ua/en/vs_pri_viznanni_statusu_bigentsya_situatsiya_v_yogo_kraini_e _dokazom_togo_shcho_poboyuvan_a_pati_girls (date of application: 15.10.2019) [in Ukrainian].

6. Ustav Upravleniia Verkhovnogo komissara OON po delam bezhentsev ot 14.12.1950. Deistvuiushcheie mezhdunarodnoie pravo. "Charter of the Office of the UN High Commissioner for Refugees dated 12/14/1950. Applicable international law". In 3 vol., compiled by Yu.M. Kolosov, E.S. Krichvikova. T. 1. M. 1997. P. 278-283. [in Russian].

7. Konventsiia pro status bizhentsiv $1951 \mathrm{r}$. "Convention on refugee status of 1951”. URL: https://zakon.rada.gov.ua/laws/show/995_011 (date of application:15.10.2019 ) [in Ukrainian].

8. Protokol shchodo statusu bizhentsiv 1967 roku. "Protocol on the Status of Refugees 1967”. URL: https://zakon.rada.gov.ua/laws/show/995011 (date of application: 15.10.2019) [in Ukrainian].

9. Nastanova z protsedur i kryteriiv vyznachennia statusu bizhentsya UVKB OON. "Guideline on procedures and criteria for determining refugee High Commissioner for Refugees UN". URL:

http://www.nsj.gov.ua/files/1425461379RSDuMarch.pdf (date of application: 15.10.2019) [in Ukrainian].

10. Pro bizhentsiv. Zakon Ukrainy vid 24.12.1993 № 3818-XII. "About refugees. Law of Ukraine dated December 24, 1993 No. 3818-XII". Vidamosti of the Verkhovna Rada of Ukraine. 1994. № 16. Art. 90. [in Ukrainian].

11. Zakon Ukrainy vid 21.06.2001 № 2557-III «Pro bizhentsiv». Law of Ukraine of 21.06.2001 No. 2557-III “On Refugees". URL: 
https://zakon.rada.gov.ua/laws/show/2557-14 (date of application: 15.10.2019) [in Ukrainian].

12. Pro bizhentsiv ta osib, yaki potrebuiut dodatkovoho abo tymchasovoho zakhystu. Zakon Ukrainy vid 08.07.2011 № 3671-VI. “About refugees and persons in need of additional or temporary protection. Law of Ukraine dated 08.07.2011 No. 3671-VI". URL: https://zakon.rada.gov.ua/laws/show/3671-17 (date of application: ) [in Ukrainian].

13. Slovnyk ukrainskoi movy $\mathrm{v} 11$ tomakh. "Dictionary of the Ukrainian language in 11 volumes". Volume 6. 1975, P. 623. URL: http://sum.in.ua/s/pobojuvannja (date of application: 15.10.2019) [in Ukrainian].

14. Herasymenko Ye.S. (2007) Do problem kryteriiv vyznachennIa bizhentsiv. "The problems of the criteria for identifying refugees". Bulletin of the Ministry of Justice of Ukraine: scientific and practical legal publication. K. № 9. P. 81 - 83. [in Ukrainian].

15. Tlumachennia UVKB OON do Konventsii OON pro status bizhentsiv. "OHCR UN Interpretation of the UN Convention on the Status of Refugees". URL: https://www.refworld.org.ru/cgi-bin/texis/vtx/rwmain/opendocpdf.pdf? reldoc $=y \& d o c i d=575 e 6 a b 24$ (date of application: 15.10.2019) [in Ukrainian].

16. Slovnyk ukrainskoi movy v 11 tomakh. "Dictionary of Ukrainian in 11 volumes". T. 6. 1975. Art. 623. URL: http://sum.in.ua/s/peresliduvannja (date of application: 15.10.2019) [in Ukrainian].

17. S. Rempell, Defining Persecution. URL: http://ssrn.com/abstract=1941006 (date of application: 15.10.2019) [in English].

18. Pozytsiia UVKB OON vid 14.03.1995. "Position of the Office of the United Nations High Commissioner for Refugees of 14.03.1995”. Practical and methodical manual. URL: http://www.nsj.gov.ua/files/1425461379RSDuMarch.pdf (date of application: 15.10.2019) [in Ukrainian].

19. Shestakova N.O. (2015) Osnovni aspekty vyznachennia poniattia «bizhenets» V mizhnarodnomu pravi. "Basic aspects of the definition of the term "refugee" in international law". Bulletin of Dnipropetrovsk University. Alfred Nobel. Legal Sciences Series. № 2. P. 26. [in Ukrainian]. 
20. Vseobshchaia deklaratsiia prav cheloveka 1948 g. "1948 Universal Declaration of Human Rights". International Law in Documents: Textbook. M., 2000. P. 101-106. [in Russian].

21. Butkevych O.V. (2004) Prava liudyny. Ukrainska dyplomatychna entsyklopediia: U 2-kh t. "Human rights". Ukrainian Diplomatic Encyclopedia: In 2 volumes / Ed.: L. V. Hubersky (Chairman) and others. K.: Knowledge of Ukraine. Vol.2. 812 p. [in Ukrainian];

22. Volchenko A. (2011) Prava liudyny. Politychna entsyklopediia. "Human rights". Political Encyclopedia. Editorial: Yu. Levenets (chairman), Yu. Shapoval (deputy chairman) and others. K.: Parliamentary Publishing House. 604 p.; [in Ukrainian];

23. Orzikh M.F. (2005) Lichnost i prava. "Personality and right". Odessa: Yuridical literature. 3012 p. [in Russian];

24. Rabinovych P.M., Khavronyuk M.I. (2004) Prava liudyny i hromadianyna: Navchalnyi posibnyk. "Human and citizen rights": textbook. K.: Attica. 464 p. [in Ukrainian].

25. Zahalna deklaratsiia prav liudyny vid 10 hrudnia 1948 roku. "Universal Declaration of Human Rights of 10 December 1948". URL: https://zakon.rada.gov.ua/laws/show/995_015. (date of application: 15.10.2019) [in Ukrainian]. 